\title{
STANDARDIZATION OF A METHOD FOR FREEZE-DRYING OF ANTIBODIES AS READY TO USE THERAPEUTIC RADIOPHARMACEUTICALS
}

\author{
WANJEH DAVID MWANZA ${ }^{1}$, ASCHALEW ALEMU MARIE ${ }^{1}$, MARIJA STERJOVA ${ }^{1}$, ZORICA $^{2}$ \\ ARSOVA-SARAFINOVSKA ${ }^{1,2}$, PAULINA EFREMOVA ${ }^{1}$, EMILIJA JANEVIK-IVANOVSKA ${ }^{1,3 *}$ \\ ${ }^{1}$ Faculty of Medical Sciences, Goce Delcev University, Krste Misirkov 10-A, 2000 Stip, Republic of Macedonia \\ ${ }^{2}$ Institute of Public Health, 50 Divizija 6, 1000 Skopje, Republic of Macedonia \\ ${ }^{3}$ University Institute for Positron-Emission Tomography, Bledski Dogovor 10, 1000 Skopje, Republic of Macedonia
}

*corresponding author: emilija.janevik@ugd.edu.mk

Manuscript received: March 2018

\begin{abstract}
Monoclonal antibodies (mAbs) are currently assessed as a significant and growing class of drugs of biological origin. The goal of our investigation was to introduce and standardize an available protocol for freeze-drying a formulation of conjugated antibody as a ready-to-use radiopharmaceutical product with therapeutic potential and to assess the stability and integrity of the obtained product. For that purpose, we introduced a shortened two-day protocol for freeze-drying of rituximab-1B4MDTPA immunoconjugate and compared the appearance of the freeze-dried product with the products of a previously reported three-day freeze-drying protocol. The qualitative assessment of the final product was performed by infrared spectroscopy of the freeze-dried cake powders, measurement of the reconstitution times of the freeze-dried cakes and comparison of gel filtration profiles of obtained products. Considering the obtained results, we can conclude that the two days freeze-drying protocol is superior to the three days protocol based on the time and energy saved. More studies on the optimization and control of the critical freeze-drying process parameters and the critical formulation attributes are also encouraged, as well as the optimization of the conjugation and labelling protocols. None of the freeze-drying protocols produced detectable fragments. The product appearance, reconstitution times and opacity on reconstitution were similar and also the ATR/FTIR spectra demonstrating that the two freeze drying protocols yield products of similar quality.
\end{abstract}

\section{Rezumat}

Anticorpii monoclonali (mAbs) sunt considerați în prezent o clasă semnificativă și în creștere de medicamente de origine biologică. Scopul prezentului studiu a fost introducerea și standardizarea unui protocol disponibil pentru uscarea prin congelare a unei formulări de anticorp conjugat ca produs radiofarmaceutic gata de utilizare cu potențial terapeutic și evaluarea stabilității și integrității produsului obținut. În acest scop, a fost introdus un protocol scurtat la două zile pentru uscarea prin congelare a imunoconjugatului rituximab-1B4M-DTPA și a fost comparat aspectul produsului obținut cu produsul unui protocol existent anterior cu durata de uscare prin congelare de trei zile. Evaluarea calitativă a produsului final a fost realizată prin spectroscopie în infraroșu a pulberilor congelate, măsurarea timpilor de reconstituire a produselor liofilizate și compararea profilurilor de filtrare a produselor obținute. Având în vedere rezultatele obținute, putem concluziona că protocolul de două zile de uscare prin congelare este superior protocolului de trei zile considerând timpul şi energia economisită. Mai multe studii privind optimizarea și controlul parametrilor critici ai procesului de uscare prin congelare și a atributelor de formulare critică sunt, de asemenea, necesare, precum și optimizarea protocoalelor de conjugare și etichetare. Niciunul dintre protocoalele de uscare prin congelare nu a produs fragmente detectabile. Aspectul produsului, timpii de reconstituire și opacitatea la reconstituire au fost similare, precum și spectrele ATR/FTIR care demonstrează că cele două protocoale de uscare prin congelare conduc la produse de calitate similară.

Keywords: therapeutic radiopharmaceuticals, freeze-drying, antibody

\section{Introduction}

Therapeutic monoclonal antibodies (TMAs) continue to grow tremendously in their clinical importance since their first use more than thirty years ago [3]. The oncological application of monoclonal antibodies has taken the same trend since the approval of the rituximab, the first approved TMA for cancer therapy [8]. Indeed, the in vivo efficacy of the antitumor TMAs has been shown to be higher than for conventional small molecular therapeutic agents for some lymphoma types [5]. A number of strategies have been devised for the improvement of TMAs for some patients that do not respond fully to the TMAs. The approaches include, among others, the deployment of antibody-drug conjugates and therapeutic radiolabelled antibodies; some of which have already obtained regulatory approval for clinical application 
FARMACIA, 2020, Vol. 68, 1

[11]. Two radiolabelled TMAs have already found approval for clinical application, ibritumomab $/{ }^{90} \mathrm{Y}$ ibritumomab tiuxetan and tositumomab/ ${ }^{131}$ I-tositumomab for the treatment of refractory or relapsed low grade CD20+ Non-Hodgkin's Lymphomas (NHLs). The benefits of using TMAs radiolabelled with energetic particle emitting radioisotopes for the targeted tumour treatment is the additional opportunity to target other tumours cells in the vicinity of the target cells through crossfire and bystander effects. The ability to target non-CD20+ tumour cells is highly beneficial, especially where the tumour exhibits heterogeneity in antigen expression. The tissue range of the emitted particles, their therapeutic efficacy and also normal tissue toxicity depend on the energy of the particles, which in turn is dictated by the particular radioisotope used. A variety of suitable particle emitting radioisotopes are available for radiolabelling TMAs for the radioimmunotherapy (RIT) of tumours. These radioisotopes differ in terms of their decay modes, half-lives, particle energies and their chemistry. Radiolabelling of the TMAs can be achieved either directly or indirectly [9]. The direct approach is feasible for radioiodination but it is unsuitable for most radiometal labelling work because TMAs lack strong chelating groups to strongly bind the radiometal cations. For clinical usefulness of a TMA based radiopharmaceutical, the in vivo thermodynamic and kinetic stability of the metal complex is vital. Hence, derivatization of the TMAs to introduce strong chelator groups is necessary. Chelator groups that are potentially useful for a variety of radiometals have already been synthesized and widely studied [2]. For trivalent radiometal cations such as Lutetium or Yttrium, the most common are DOTA (tetraazacyclododecane1, 4, 7, 10-tetraacetic acid) and DTPA (diethylenetriaminepentaacetic acid) derivatives.

All the currently approved RIT radiopharmaceuticals are formulated as liquid preparations. The challenges associated with such formulations are instability of the antibody in storage and a cumbersome radiolabelling process. The stability of antibodies in their low concentration solutions is very low, hence their short shelf life and a strict demand for cold-chain transportation and storage. The cumbersome radiolabelling procedure increases the risk for confusions and poor quality of the labelled preparations. For that reason, it is necessary to produce a more stable radiopharmaceutical kit preparation that is easier to radiolabel (preferably in a one-step process), has a long shelf life in storage and does not require strict cold-chain conditions during distribution. One such strategy is the employment of freeze-drying technology. Freeze-drying is a widely studied and applied technology. It helps to produce sufficiently dry preparations of thermolabile drug substances with high porosity and fast dissolution during reconstitution. Its application in the production of biotechnological pharmaceutical products is already well established [4]. The freeze-drying process removes almost all the water from the solution, thereby yielding a more stable product that weighs less, is easy to store and fast to reconstitute.

In this study, the suitability of an improved freezedrying protocol was investigated for the preparation of a ready-to-use freeze dried formulation of rituximab immunoconjugate with $p$-SCN-Bn-1B4M-DTPA (2(4-isothiocyanatobenzyl)-6-methyl-di-ethylenetriaminepentaacetic acid) as a potential therapeutic radiopharmaceutical.

\section{Materials and Methods}

\section{Purification of rituximab}

MabThera ${ }^{\circledR}$ (Hoffmann-La Roche, Basel, Switzerland) was subjected to ultrafiltration using Amicon $^{\circledR}$ Ultra-4 (Sigma Aldrich, Missouri, USA) $30 \mathrm{kDa}$ membranes and HuMax 4k (Human, Wiesbaden, Germany) centrifuge. Six one-hour filtration cycles at a centrifugation speed of $5000 \mathrm{rpm}$ adequately purified rituximab from MabThera ${ }^{\circledR}$. At the end of every cycle, the antibody was washed with $0.1 \mathrm{M}$ phosphate buffer, $\mathrm{pH}=8.0$.

\section{Conjugation of rituximab}

The purified rituximab was mixed with $10 \mathrm{mg} / \mathrm{mL}$ solution of 1B4M-DTPA in a 1:20 ratio and then incubated for 18 hours at $4^{\circ} \mathrm{C}$ with gentle shaking. Purification of the immunoconjugate was performed by subjecting the conjugation mixture to six onehour cycles of ultrafiltration using Amicon ${ }^{\circledR}$ Ultra-4 (Sigma Aldrich, Missouri, USA) $30 \mathrm{kDa}$ membranes and HuMax 4k (Human, Wiesbaden, Germany) centrifuge, at a centrifugation speed of $5000 \mathrm{rpm}$. At the end of every cycle, the antibody was washed with $0.1 \mathrm{M}$ phosphate buffer, $\mathrm{pH}=8.0$. The immunoconjugate concentration was determined using the 6715 UV/Vis Spectrophotometer Jenway ${ }^{\circledR}$ (Staffordshire, UK) and then adjusted to $1 \mathrm{mg} / \mathrm{mL}$ using $0.1 \mathrm{M}$ phosphate buffer, $\mathrm{pH}=8.0$.

Freeze-drying of rituximab and rituximab-immunoconjugate

One $\mathrm{mL}$ aliquots of the antibody or immunoconjugate solutions were transferred into type I glass vials and freeze dried according to the referred protocol [6] and the modified two days protocol described below. The antibody and the immunoconjugate were freezedried with Labconco Free Zone Stoppering Tray Dryer (Kansas City, Missouri, USA). All the formulations were devoid of any cryoprotectant. For the two-day freeze-drying protocol, $1 \mathrm{~mL}$ aliquots of purified 1 $\mathrm{mg} / \mathrm{mL}$ rituximab in $0.1 \mathrm{M}$ phosphate buffer $\mathrm{pH} 8.0$ dispensed into $10 \mathrm{~mL}$ type 1 glass vials at $2-8^{\circ} \mathrm{C}$. The vials were partially closed with freeze-drying metal-free rubber stoppers and loaded into the freeze drier at shelf temperature of $4^{\circ} \mathrm{C}$. The shelf temperature was maintained at $4^{\circ} \mathrm{C}$ for $30 \mathrm{~min}$. 
Then, it was lowered at a rate of $1{ }^{\circ} \mathrm{C} / \mathrm{min}$ to $-40^{\circ} \mathrm{C}$, held for 5 hours for the freezing phase before the vacuum pump was turned on. The subsequent phases were performed at chamber pressures of $0.12 \mathrm{mBar}$. At a rate of $0.15^{\circ} \mathrm{C} / \mathrm{min}$, the shelf temperature was raised to $-10^{\circ} \mathrm{C}$ and held at the same temperature for 28 hours for the primary drying phase. At the end of the primary drying phase, the shelf temperature was elevated at a rate of $0.2^{\circ} \mathrm{C} / \mathrm{min}$ to $25^{\circ} \mathrm{C}$ and held at the $25^{\circ} \mathrm{C}$ for 14 hours for the secondary drying phase to complete. At the end of the secondary drying, the chamber vacuum was released with atmospheric air. The vials were stoppered and stored at $2-8^{\circ} \mathrm{C}$ pending further investigations. The two protocols of freeze-drying are shown in Figure 2 and Figure 3. In total, four production runs of 11 vials each were performed. The referred protocol and the two days protocol were used to produce 44 vials of freeze-dried product, 11 vials each for rituximab and immunoconjugate.

Measuring the reconstitution times of the solid samples

A sample of six (6) vials was taken from each of the four different production batches, described above, for determination of the reconstitution times. The reconstitution times were determined with a stopwatch by adding $1 \mathrm{~mL} 0.9 \%$ saline solution to the sampled solid preparations and shaking gently. The obtained data was analysed using student's t-test.

Fourier Transform Infrared (FTIR) spectroscopy of liquid and solid samples

Infrared spectroscopy was performed for both solid and liquid samples of rituximab commercial product $\left(\right.$ MabThera $\left.^{\circledR}\right)$, purified non-freeze-dried rituximab, non-freeze-dried immunoconjugate of 1B4mDTPA, and for the freeze-dried preparations of rituximab and the immunoconjugate of rituximab-1B4mDTPA.

The freeze-dried rituximab and freeze-dried immunoconjugate were reconstituted with $1 \mathrm{~mL} 0.1 \mathrm{M}$ phosphate buffer $\mathrm{pH}=8.0$ and scanned using PARAGON 1000 ATR-FTIR spectrometer (Perkin Elmer).

\section{Results and Discussion}

The method for freeze-drying of the antibody and antibody conjugate was standardized. The purification of the commercial product in order to obtain a pure antibody was important for both immuno-conjugation and freeze-drying. Size exclusion chromatography (SEC) was used to assess the effectiveness of the purification process as shown in Figure 1.
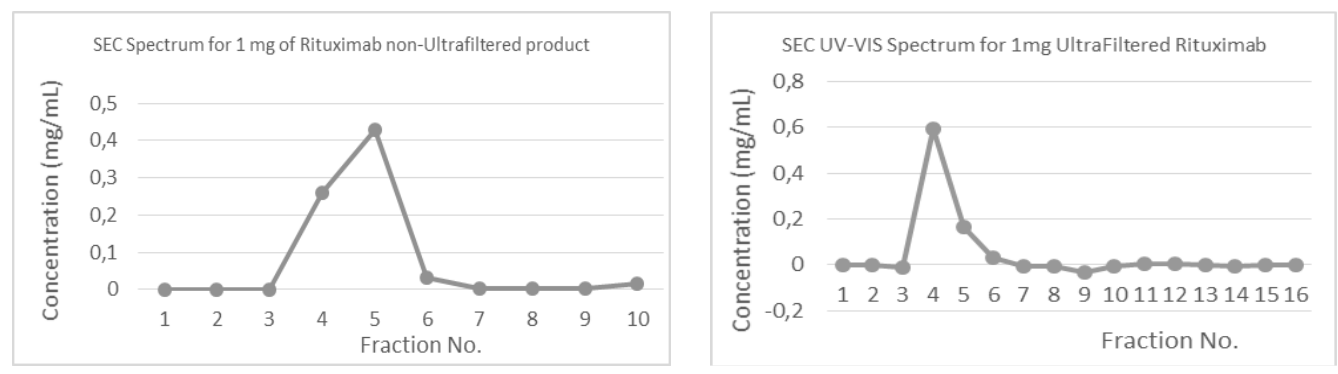

Figure 1.

Comparison of the SEC spectra for non-purified and purified rituximab solution

Choosing the most appropriate standardized freezedrying protocol is crucial to obtain a stable kit formulation of antibody conjugate suitable for the subsequent usage, such as for labelling with different radioisotopes as a ready to use radiopharmaceutical. Gjorgieva Ackova et al. used the three days protocol
(Figure 2) for preparing the same kit [6]. In the present work we wanted to assess the three-day protocol and also to introduce and standardize a shorter (two-day protocol) with the objective of obtaining a final product of the same quality, stability and labelling yield.

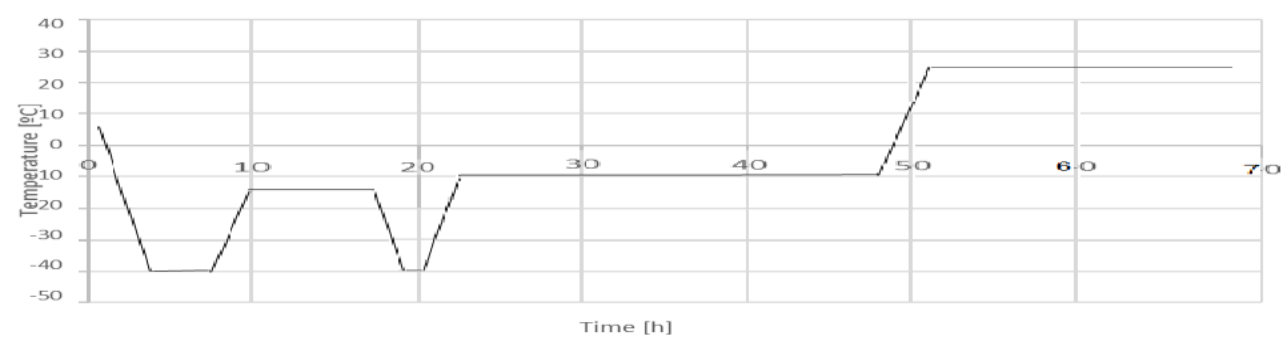

Figure 2.

Graphic scheme of the three-day freeze-drying protocol 
FARMACIA, 2020, Vol. 68, 1

In Table I and Table II the freeze-drying cycles of both protocols are described. From the Figures 2 and 3, the two-day protocol is devoid of the annealing step and the ramping times are shorter.

Table I

Reference three days freeze-drying cycle

\begin{tabular}{|c|c|c|c|}
\hline Segment & Freezing temperature & RAMP(Speed) & Holding Time \\
\hline 1(Pre-freezing) & Room Temp to $4^{\circ} \mathrm{C}$ & $0.4^{\circ} \mathrm{C} / \mathrm{min}$ & 30 minute \\
\hline \multirow{2}{*}{ 2(Freezing) } & $4^{\circ} \mathrm{C}$ to $-45^{\circ} \mathrm{C}$ & $0.4^{\circ} \mathrm{C} / \mathrm{min}$ & 3 hours \\
\cline { 2 - 4 } & $-45^{\circ} \mathrm{C}$ to $-15^{\circ} \mathrm{C}$ & $0.15^{\circ} \mathrm{C} / \mathrm{min}$ & 6 hours \\
\cline { 2 - 4 } & $-15^{\circ} \mathrm{C}$ to $-4^{\circ} \mathrm{C}$ & $0.2^{\circ} \mathrm{C} / \mathrm{min}$ & 2 hours \\
\hline 3(Primary Drying) & $-45^{\circ} \mathrm{C}$ to $-10^{\circ} \mathrm{C}$ & $0.15^{\circ} \mathrm{C} / \mathrm{min}$ & 28 hours \\
\hline 4(Secondary Drying) & $-10^{\circ} \mathrm{C}$ to $25^{\circ} \mathrm{C}$ & $0.15^{\circ} \mathrm{C} / \mathrm{min}$ & 14 hours \\
\hline
\end{tabular}

Table II

Proposed two days freeze-drying cycle

\begin{tabular}{|c|c|c|c|}
\hline Segment & Freezing temperature & RAMP(Speed) & Holding Time \\
\hline 1(Pre-freezing) & Room Temp to $4^{\circ} \mathrm{C}$ & $1.0^{\circ} \mathrm{C} / \mathrm{min}$ & 30 minute \\
\hline 2(Freezing) & $4^{\circ} \mathrm{C}$ to $-45^{\circ} \mathrm{C}$ & $1.0^{\circ} \mathrm{C} / \mathrm{min}$ & 5 hours \\
\hline 3(Primary Drying) & $-45^{\circ} \mathrm{C}$ to $-10^{\circ} \mathrm{c}$ & $0.15^{\circ} \mathrm{C} / \mathrm{min}$ & 28 hours \\
\hline 4(Secondary Drying) & $-10^{\circ} \mathrm{C}$ to $25^{\circ} \mathrm{c}$ & $0.2^{\circ} \mathrm{C} / \mathrm{min}$ & 14 hours \\
\hline
\end{tabular}

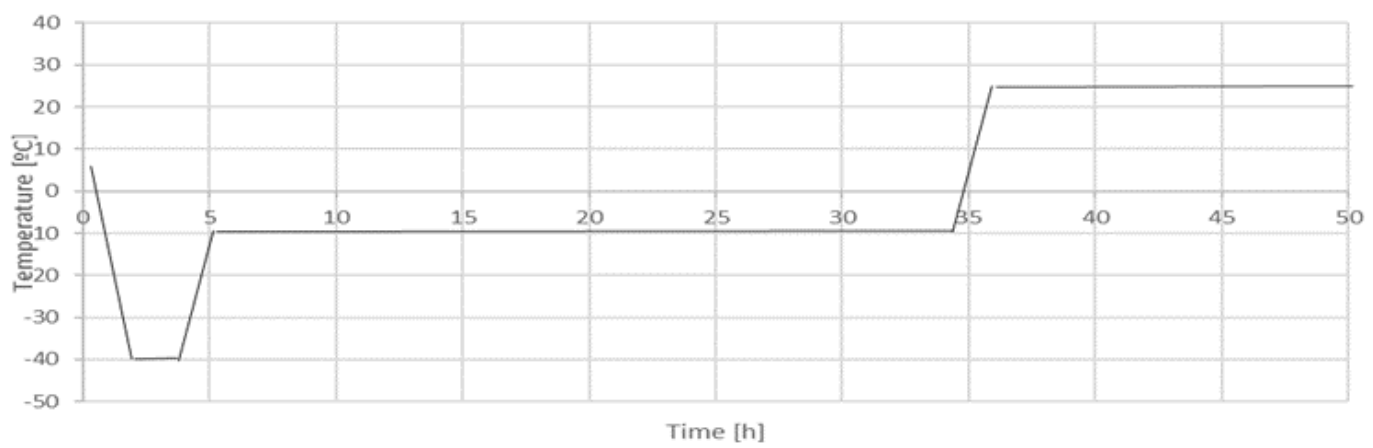

Figure 3.

Graphic scheme for the two-day freeze-drying protocol

After freeze-drying, the size and appearance of the obtained "cakes" of the antibody and immuno- conjugate were compared. As we can see from the Figure 4, the cake looks more consistent and contracted.

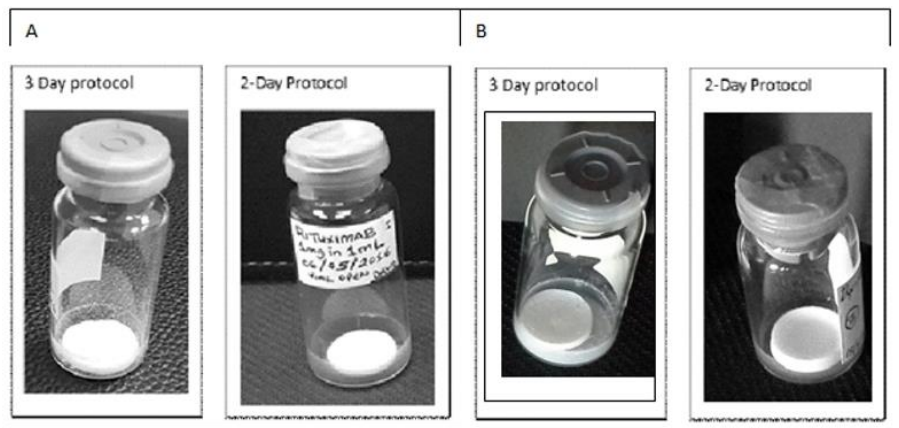

Figure 4.

A) Freeze-dried antibody for for three day and two day freeze-drying protocols; B) Freeze-dried immunoconjugate for three day and two day freeze-drying protocols

After the reconstitution of the freeze-dried antibody and immunoconjugate the time needed to obtain clear and clearness solution was measured as presented in the Tables IV and V. The reconstitution times for the products of two freeze drying protocols were analysed for statistical difference using Microsoft
Excel student's t-test assuming unequal variance. Reconstitution times from the two days freeze drying protocol were significantly shorter; $\mathrm{p}<0.05$. As is visible from Figure 5, the solution of the products of three days and two days freeze-drying protocols have similar clarity on visual inspection. 
Table III

Reconstitution times in seconds of the freeze-dried antibody

\begin{tabular}{|c|c|c|c|c|c|c|c|}
\hline Vial No & 1 & 2 & 3 & 4 & 5 & 6 & Mean \\
\hline 3 Day protocol & 80.56 & 75.25 & 82.07 & 77 & 73.92 & 78.38 & $77.86 \pm 3.11$ \\
\hline 2 Day protocol & 65.79 & 68.72 & 71.2 & 69.18 & 68.21 & 67.17 & $68.38 \pm 1.84$ \\
\hline
\end{tabular}

Table IV

Reconstitution times in seconds of the of freeze-dried immunoconjugate

\begin{tabular}{|c|c|c|c|c|c|c|c|}
\hline Vial No. & 1 & 6 & 7 & 8 & 9 & 10 & Mean \\
\hline 3 Day protocol & 33.27 & 33.01 & 35.86 & 30.98 & 31.52 & 34.71 & $33.23 \pm 1.85$ \\
\hline 2 Day protocol & 26.23 & 28.92 & 32.00 & 29.13 & 29.51 & 32.96 & $29.79 \pm 2.40$ \\
\hline
\end{tabular}
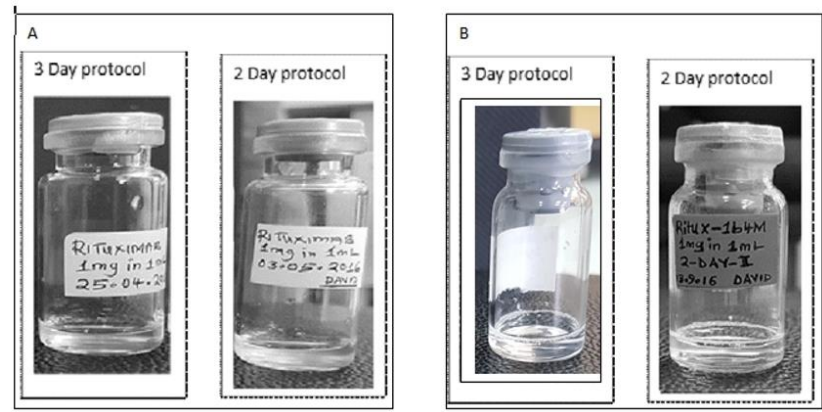

Figure 5.

Clarity of the reconstituted products using two-day and the three-day freeze drying protocols. A) Solution of reconstituted freeze-dried antibody B) Solution of reconstituted freeze-dried immunoconjugate

The reconstituted freeze-dried antibodies and immunoconjugates were tested using SEC to see destruction of the complex and presence of aggregates after freeze drying. As seen from the SEC spectra in Figure 6, the peak of the product from the three-day protocol was broader (encompassing fraction numbers 4, 5, 6, 7) than the peak obtained from the product of the twoday freeze-drying protocol (contributed by fractions
$4,5,6)$. The concentration of the antibody after two days protocol showed a higher specific concentration. The conjugated antibody (rituximab-1B4mDTPA) was freeze dried using the two days protocol and the integrity of the protein, purity and possible formation of aggregates was examined using SEC as showed on Figure 7.
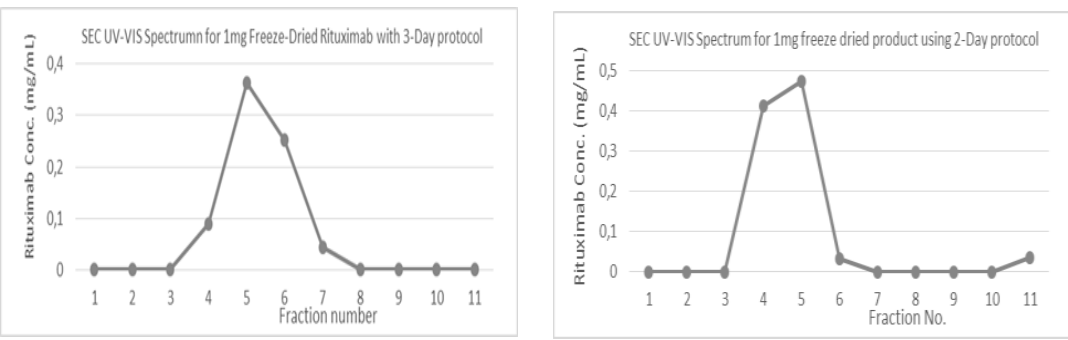

Figure 6.

Comparison the SEC spectra of rituximab from the three-day and the two-day freeze drying protocols

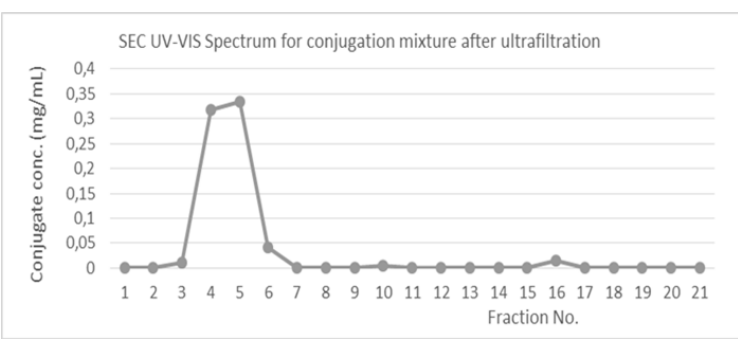

Figure 7.

SEC spectrum with UV-VIS detection of the freeze-dried immunoconjugate using two days protocol 
The molecular structural integrity of the antibody and immunoconjugate in liquid formulations and solid formulations after freeze drying using three days and two days protocols were investigated using Fourier transform infrared (FTIR) spectroscopy.

The ATR/FTIR spectra of the three days and two days freeze-dried rituximab in Figures 8 and 9 showed no difference in the structural integrity, and it was also similar with the non-freeze-dried commercial rituximab liquid product, as seen in Figure 10. The same FTIR analyses were performed on the rituximab1b4mDTPA immunoconjugate in liquid form before freeze drying using two days protocol, after freezedrying in a solid form and on the reconstituted freeze dried immunoconjugate.

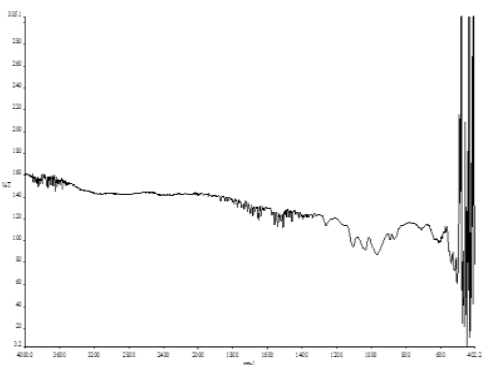

Figure 8.

ATR/FTIR spectra for three-day freeze-dried rituximab product

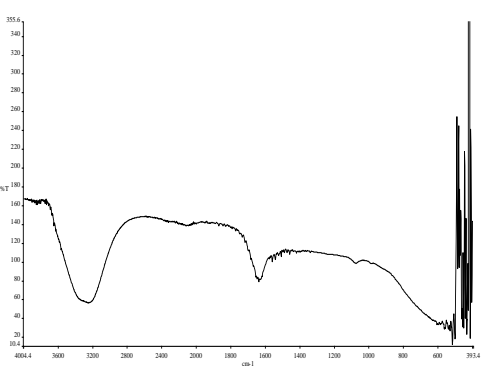

Figure 11.

ATR/FTIR spectra of solution of non-freeze-dried rituximab1b4mDTPA immunoconjugate

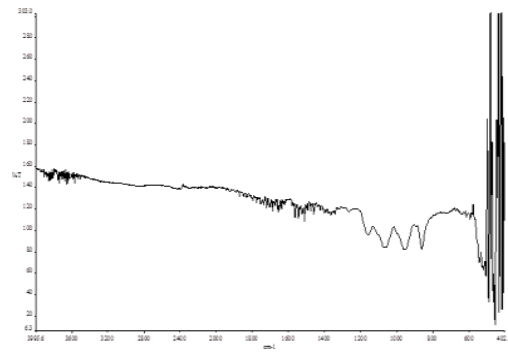

Figure 9.

ATR/FTIR spectra for two-day freeze-dried rituximab product

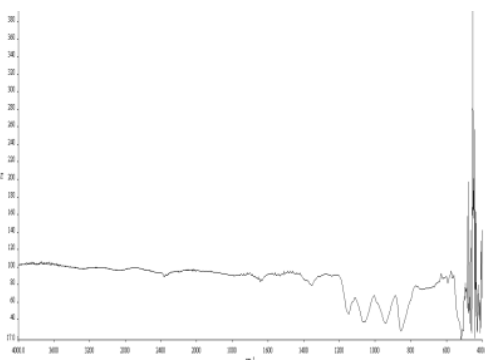

Figure 12.

ATR/FTIR spectra for powder two day freeze-dried rituximab1b4mDTPA immunoconjugate

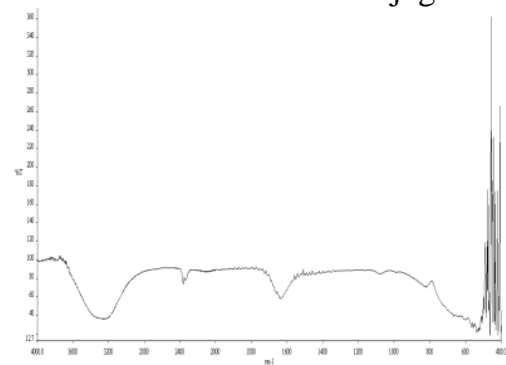

Figure 14.

ATR/FTIR spectra for ultra-filtered non-freeze-dried rituximab1b4mDTPA solution

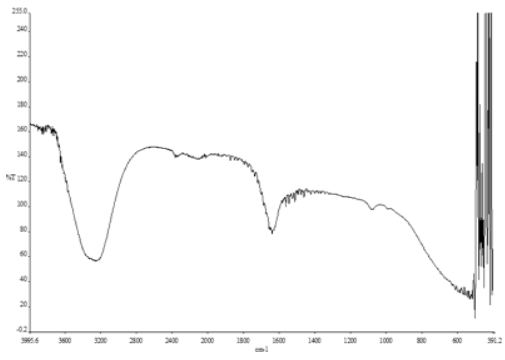

Figure 10.

ATR/FTIR spectra for non-freezedried commercial rituximab liquid product

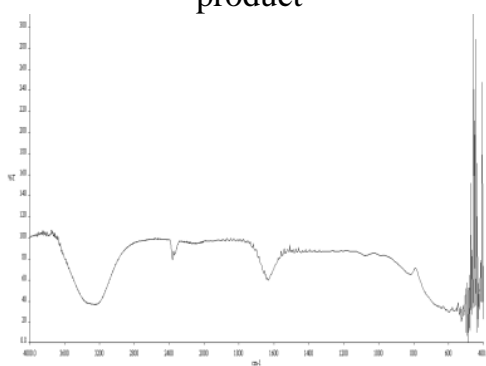

Figure 13.

ATR/FTIR spectra for a solution of two days freeze-dried rituximab1b4mDTPA
Freeze-drying is an important technology in the production of stable ready-to-use radiopharmaceutical kit preparations. Ideally, a freeze-drying protocol should not affect the chemical structure of the active principle ingredient. It should also result in stable, uniform cakes that retain the characteristics of the active molecule on reconstitution [1].

The freeze-drying protocol that was used, standardized and adopted is the two-day protocol and it was compared with the already used three-day freeze drying method for preparing kit formulations containing rituximab-1b4mDTPA [7]. The reason was to provide faster time of freeze drying, higher stability of the final product, higher or same quality and good radiolabelling yield and to exclude the annealing step. Firstly, the freezing rate used was elevated from the referred $0.4^{\circ} \mathrm{C} / \mathrm{min}$ to a cooling rate of $1^{\circ} \mathrm{C} / \mathrm{min}$. According to a review of Tang and Pikal [10], the cooling rate of $1^{\circ} \mathrm{C} / \mathrm{min}$ achieves super cooling without phase separation and a uniform ice structure. A bulk 
of the frozen water is removed during the primary drying phase by sublimation in a vacuum environment. To ensure completeness of the primary drying phase, a primary drying time of 28 hours was used. During the secondary drying phase unfrozen bound water is removed at higher temperatures, commonly $25^{\circ} \mathrm{C}$. A secondary drying time of 14 hours was used.

The products emanating from the two freeze-drying protocols were compared in terms of their cake appearance, mean reconstitution times, SEC UVVIS spectra and FTIR spectra. Also, a comparison of the SEC UV-VIS and FTIR spectra of the freezedried products and the non-freeze-dried rituximab solution was made so as to assess the effect of each protocol on the drug substance.

Ideally, freeze-dried products should be uniform and elegant in appearance. This is however not always the case and some of the commonest variations noticed include meltback, collapse, cracking, shrinking, etc. The cake in this study reveals shrinkage. Shrinkage is a phenomenon that is contributed to by many factors including product-container surface interactions. Cake shrinkage may or may not impact on the critical quality attributes of a freeze-dried product. When a determination of the antibody concentration in the reconstituted freeze-dried samples was made using UV-Vis spectrophotometry, no significant differences were observed between the antibody concentrations before and after freeze-drying. Thus, the cake appearance was not associated with a change in the product critical quality attributes.

Another quality attribute of a freeze-dried product is its reconstitution time. In comparing the rituximab products of the two protocols, the two days protocol results were significantly lower considering the mean reconstitution times and this was considered as more desirable with respect to this quality attribute. As seen in Table III, the mean reconstitution times for the three-day and two-day protocols are 77.86 \pm 3.11 seconds and $68.38 \pm 1.84$ seconds respectively. Using two tailed t-test assuming unequal variance, calculated with Microsoft Excel, it was determined that the difference between the mean values above was statistically significant considering an alpha value of $0.05(\mathrm{p}=0.0002)$. The two-day protocol, for yielding lower reconstitution times in the study circumstances, was considered more desirable to the three-day protocol.

The mean reconstitution time for the immunoconjugate, freeze-dried using the two days freezedrying protocol, was $29.79 \pm 2.40$ seconds. Considering that a similar rituximab formulation freeze-dried using the two-day protocol had a mean reconstitution time of $68.38 \pm 1.84$, the observation confirmed that different substances may respond differently to similar freeze-drying conditions. Hence, one freeze drying protocol may work differently for different substances or different formulations. For optimum product characteristics, a freeze-drying protocol needs to be tailor-made and fine-tuned for every substance or formulation.

SEC is a useful method for assessing protein-based formulations for impurities such as fragments and aggregates. In this study, the samples were eluted through $10 \mathrm{~mL}$ columns of G25 Sephadex gel and 1 $\mathrm{mL}$ fractions were collected into cuvettes that were assessed using a UV-VIS detector. The cuvette fractions were chronologically plotted against their corresponding concentrations that were calculated from their respective absorbance, producing SEC UV-VIS spectra of the tested products.

The desired picture for non-conjugated freeze-dried rituximab is that of a narrow peak consisting of fractions 4 and 5, with fraction 5 containing the higher concentrations as seen with the non-freeze-dried rituximab in Figure 10. As reported in Figure 6 and juxtaposed in Figure 1, the two-day freeze-drying protocol product depicted a picture closer to the non-freeze-dried rituximab than the three-day one. The higher protein concentration detected in fraction number 6 of the three-day protocol that was almost absent in the non-freeze-dried rituximab solution. In addition, the spectrum from the three-day protocol's product showed absorbance in fraction number 7 , which was absent altogether from the two-day protocol's spectrum and the non-freeze-dried rituximab solution's spectrum. Based on that assessment and regarding the SEC spectrum with UV-VIS detection of the freeze dried immunoconjugate using the two days protocol in Figure 7, the two-day freeze-drying protocol was considered more appropriate.

To make an assessment of any structural distortions to the antibody that may have resulted from the freezedrying processes, FTIR spectroscopy was performed on both the products before and after freeze drying. As shown in the Figures 8-14, the fingerprint regions of the samples are identical to that of their nonfreeze-dried counterparts. That was a demonstration that the molecule was not significantly altered by the freeze-drying process.

The FTIR technique was useful for analysis of the secondary structure of proteins, including antibodies. By using Fourier transform second derivative (FSD), or other techniques, the percentages of the different secondary structures can be calculated from the areas under their respective curves in the absorption peaks. If the secondary structure composition of the non-freeze-dried antibody is known, it can be juxtaposed with that of the freeze-dried antibody so as to assess structural integrity post freeze-drying. Analysis of the freeze-dried antibody rituximab and freeze-dried conjugate, even though without FSD, showed close similarity in the FTIR spectra with the non-lyophilized rituximab antibody (Figures 8 - 14). The close-fitting spectra between the test (freeze dried) samples and the reference (non-lyophilized) 
samples demonstrated a preservation of the structural integrity post freeze-drying.

\section{Conclusions}

The presented results have shown that freeze drying is a promising method for establishing ready to use formulations for many proteins and peptide-based radiopharmaceuticals. The integrity and stability of the antibody were retained after freeze drying and purification steps. From our study we can conclude that the two days freeze drying protocol is superior to the three days protocol based on the time and energy saved, even though the freeze-drying protocols of two days and three days yielded products of similar quality. None of the freeze-drying protocols produced detectable fragments. The cake appearance, reconstitution times and opacity on reconstitution were similar and ATR/FTIR spectra demonstrated that the two freezedrying protocols yield products of similar quality.

\section{Acknowledgement}

This research was supported by The International Atomic Energy Agency.

\section{Conflict of interest}

The authors declare no conflict of interest.

\section{References}

1. Bedu-Addo FK, Understanding lyophilization formulation development. PharmTech., 2004; 10-18.

2. Brechbiel MW, Bifunctional chelates for metal nuclides. Q J Nucl Med Mo. Imaging, 2008; 52(2): 166-173.
3. Ecker DM, Jones SD, Levine HL, The therapeutic monoclonal antibody market. MAbs, 2015; 7(1): 9-14.

4. Ekenlebie E, Einfalt T, Karytinos AI, Ingham A, Pharmaceutical patent applications in freeze-drying. Pharm Pat Anal., 2016; 5(6): 407-416.

5. Else M, Marín-Niebla A, de la Cruz F, Batty P, Ríos E, Dearden CE, Catovsky, D, Matutes E, Rituximab, used alone or in combination, is superior to other treatment modalities in splenic marginal zone lymphoma. Br J Haematol., 2012; 159(3): 322-328.

6. Gjorgieva Ackova D, Smilkov K, JanevikIvanovska E, Formulation and characterization of "Ready to Use" 1B4M-DTPA-rituximab for Lu-177 labeling. World J Med Sci., 2014; 11(4): 535-540.

7. Gjorgieva Ackova D, Smilkov K, JanevikIvanovska E, Stafilov T, Arsova-Sarafinovska Z, Makreski P, Evaluation of non-radioactive lutetium- and yttrium-labeled immunoconjugates of rituximab - a vibrational spectroscopy study. Maced J Chem Chem Eng., 2015; 34: 351-362.

8. Reichert JM, Valge-Archer VE, Development trends for monoclonal antibody cancer therapeutics. Nat Rev Drug Discov., 2007; 6: 349-356.

9. Sugiura G, Kühn H, Sauter M, Haberkorn U, Mier W, Radiolabeling strategies for tumor-targeting proteinaceous drugs. Molecules, 2014; 19(2): 21352165.

10. Tang XT, Pikal MJ, Design of freeze-drying processes for pharmaceuticals: Practical advice. Pharm Res., 2004; 21(2): 191-200.

11. Ujjani C, Cheson BD, The current status and future impact of targeted therapies in non-Hodgkin lymphoma. Expert Rev Hematol., 2013; 6: 191-203. 